\title{
Indonesia's 1989 Religious Judicature Act: Islamization of Indonesia or Indonesianization of Islam?
}

\section{Mark Cammack'}

\section{Introduction}

In 1989 the Indonesian legislature passed and President Suharto signed a new law governing the country's Islamic courts. The statute, known as the Religious Judicature $\mathrm{Act}^{2}$ (the Act), significantly enhanced the legal and institutional standing of the Islamic courts by providing formal legal guarantees of their security and increasing the level of state support. The Act also expanded and equalized the courts' powers. Prior to the passage of the Act the substantive competence of Islamic courts on the populous islands of Java and Madura extended only to matters of marriage and divorce. The 1989 Act expanded the Islamic courts' jurisdiction to include inheritance throughout the country. The Act also strengthened the standing of the Islamic courts in relation to the civil courts by eliminating a rule dating from the nineteenth century which had required that decisions of Islamic courts must be ratified by a civil court to be enforceable.

The enactment of the Religious Judicature Act seemed to signal a reversal in New Order policy on the role of religion in public life and the enforcement of Islamic law.

\footnotetext{
${ }^{1}$ Research for this article was supported by a grant from Southwestern University School of Law. I also wish to thank the editors and anonymous readers for Indonesia who provided valuable comments on an earlier version of this manuscript.

${ }^{2}$ The Act is designated as Law No. 7 (1989).
} 
144 Mark Cammack

Although Islamic interests provided critical support in President Suharto's rise to power in the mid-1960s, the regime's actions over the ensuing two decades did not support Islamic involvement in the exercise of state power. Once in control, the New Order set about systematically to neutralize Islam as a basis for political and legal mobilization. Most observers in the 1970s would have found it unthinkable that in the 1990s the Suharto government would be actively promoting state enforcement of Islamic doctrine.

This article seeks to place these recent developments in Islamic law in a broader context, and qualifies the initial assessment of their importance. Though significant, the Religious Judicature Act does not mark the dramatic shift in policy that at first blush it seems to indicate. Rather, it is to a large extent the culmination of events set in motion twenty years earlier. Moreover, while the Suharto government is clearly presenting a more Islamic demeanor, it has not abandoned its historic policy of controlling Islamic law and politics.

The next section of the article provides a brief historical introduction to the Islamic courts in Indonesia as background to more recent developments. In Part III I survey the key provisions of the 1989 Act and point out changes it makes to prior law. Part IV looks more closely at one specific issue treated in the Act-divorces initiated by mento illustrate my thesis that recent events are largely continuous with policies established a quarter century earlier.

\section{Historical Background to the 1989 Act}

Islamic judicial institutions have operated in island Southeast Asia for centuries, ${ }^{3}$ but the lineage of the present Indonesian Islamic courts is commonly traced to a Dutch Royal Decree of 1882 . That Decree formally chartered a system of Islamic tribunals called "Priests' Councils" (priesterraden) to operate alongside the existing ordinary

${ }^{3}$ Information about the administration of Islamic justice before the advent of European records is scattered and scarce. Anthony Reid has written that by the early seventeenth century, the major Islamic states in the region had established regular institutions for the implementation of Islamic law, although there is definite evidence for the existence of Islamic courts per se only in Aceh and Banten. See Anthony Reid, Southeast Asia in the Age of Commerce, 1450-1680, Volume II: Expansion and Crisis (New Haven: Yale University Press, 1993), pp. 182-84. Martin van Bruinessen has analyzed records from Banten, where the chief Islamic judge was appointed by the Sultan from at least the beginning of the seventeenth century until the office was abolished with the consolidation of Dutch control over the area in the middle of the nineteenth. Though originally an all-purpose religious official, over time the office of chief judge acquired a narrower adjudicative function. From the eighteenth century on, the chief judge exercised jurisdiction over all non-capital cases and administered a hierarchy of subordinate judges who heard cases at the district level. Martin van Bruinessen, "Shari' a court, tarekat and pesantren: Religious Institutions in the Banten Sultanate," Archipel 50 (1995): 165, 168-72. Among the Javanese, the administration of Islamic justice was one of several functions performed by the penghulu--the chief administrator of the mosque-who conducted judicial proceedings in the portico of the mosque. The penghulu were appointed by and closely linked with the local aristocracy and stood in contrast to the other principal religious elite, the heads of Islamic boarding schools, who remained independent of political authority and had large mass followings. Although the reach of the penghulu's jurisdiction and the extent of the influence of Islamic doctrine is uncertain, the penghulu were apparently the primary judicial officers for the Javanese. See Daniel Lev, Islamic Courts in Indonesia: A Study in the Political Bases of Legal Institutions (Berkeley: University of California Press, 1972), pp. 10-13. 
courts in Java and Madura. ${ }^{4}$ The courts were to consist of the penghulu-the chief religious official of the district-and from three to eight members, with a minimum of three required to constitute a quorum. ${ }^{5}$ The collegial character of the courts was a Dutch innovation, apparently based on a misunderstanding of contemporary practice in which the penghulu, not well versed in the law, took advice from others who were more learned. 6 Although the penghulu received a small civil service salary in his capacity as religious advisor to the civil court, the member judges were not civil servants and received no government compensation. Instead, they served on a per session basis and were compensated out of fees paid directly by litigants and a share of the estate in inheritance cases, which was also a principal source of emolument for the chairmen. ${ }^{7}$ Under an earlier regulation issued in the 1830s, Islamic court decisions had to be ratified by a civil court to be enforceable. ${ }^{8}$

The next significant intervention in the administration of Islamic law occurred in the 1930s. A series of regulations in 1937 called for a number of changes to the courts in Java and Madura, which were renamed "Penghulu Courts" (penghulu-gerecht), and established new tribunals, called "Kerapatan Qadi," in South Kalimantan.9 The regulations provided for the payment of salaries to the court chairmen and the addition of a salaried clerk. These reforms, which were not actually implemented for nearly a decade, ${ }^{10}$ were intended to promote the independence of the courts by reducing or eliminating their dependence on exactions from litigants, and to make them more modern and efficient. The regulations also provided for the formation of Islamic appeals courts, a change that had been recommended by $C$. Snouck Hurgronje, the renown Islamicist and colonial advisor on native affairs, as a means of promoting

${ }^{4}$ The Decree is designated Staatsblad (State Gazette) No. 152 (1882). For a discussion of the enactment see Harry J. Benda, The Crescent and the Rising Sun: Indonesian Islam under the Japanese Occupation, 1942-1945 (The Hague: W. van Hoeve, 1958), pp. 83-85; Lev, Islamic Courts, pp. 13-14; H. Z. A. Noeh and H. A. B. Adnan, Sejarah Singkat Pengadilan Agama Islam di Indonesia (Jakarta: Bina Ilmu, 1983), pp. 32-35; and Karel Steenbrink, Beberapa Aspek tentang Islam di Indonesia Abad ke-19 (Jakarta: Bulan Bintang, 1984), pp. $220-223$.

5 Lev, Islamic Courts, p. 14.

${ }^{6}$ Benda, The Crescent and the Rising Sun, p. 84; Steenbrink, Islam di Indonesia Abad ke-19, pp. 221-222.

${ }^{7}$ Noeh and Adnan, Sejarah Singkat, p. 33.

8 Steenbrink, Islam di Indonesia Abad ke 19, p. 217. Although the 1882 edict served as the legal charter for Islamic courts in Java and Madura for more than a century, that was probably not the intention of the colonial officials who formulated the law. To begin with, at the time the recommendations for the Islamic courts were forwarded to Den Haag there was substantial support among Dutch officials in the Indies for abolishing Islamic courts altogether. Steenbrink, Islam di Indonesia Abad ke-19, p. 220. And while the consensus favored continuation of the courts, some of those who joined the recommendation did so for political reasons with the anticipation that the courts would eventually be abolished. Ibid. More importantly, Harry Benda's assessment that the 1882 decree was not intended to vest judicial power in the penghulu is probably correct. Benda, The Crescent and the Rising Sun, 84. The requirement of an executory decree for the pronouncements of the penghulu's courts to be enforceable meant that, "[s]trictly speaking, the members of these councils were ... no more judges than they were 'priests,' even in matters pertaining to their alleged jurisdiction." Ibid.

${ }^{9}$ Staatsblad Nos. 116, 610, 639 (1937) discussed in Benda, The Crescent and the Rising Sun, pp. $83-88$ and Lev, Islamic Courts, pp. 17-21. The reforms carried out in the 1930 s were based on the report of a committee that had been set up in 1922 to study the Islamic courts. The Committee's recommendations were first embodied in a regulation issued in 1931, Staatsblad No. 53 (1931), which was not implemented until 1937 because of budgetary constraints resulting from the depression. Lev, Islamic Courts, pp. 17-18.

10 Lev, Islamic Courts, p. 64. 
146 Mark Cammack

more informed and uniform decision making. ${ }^{11}$ This aspect of the law was implemented with the formation of the Kerapatan Qadi Besar in Banjarmasin to serve the new courts in Kalimantan and the Mahkamah Islam Tinggi for Java and Madura. ${ }^{12}$

The most significant change made in 1937 related to the jurisdiction of the courts. The law transferred authority over inheritance from Islamic to civil tribunals. ${ }^{13}$ This left the Islamic courts with jurisdiction over marriage and divorce only. The same limitation was also applied to the new courts in South Kalimantan. The elimination of Islamic inheritance jurisdiction reflected the views of the so-called adat law school, a group of Dutch scholars and their Indonesian students who favored neither Islamic nor Dutch legal institutions but the customary rules (adat) of the archipelago's numerous ethnic groups. ${ }^{14}$ The priority given to adat over Islam found legal expression in the so-called reception theory, which holds that Islamic rules have the force of law only insofar as they have been received into the local adat. ${ }^{15}$ Apart from the doctrine's practical significance in restricting the applicability of Islamic law, shariah oriented Indonesians have, since its inception, considered the reception theory especially pernicious because of its denial of any independent standing for Islamic law. ${ }^{16}$

In preferring adat over Islam, the Dutch scholars of Indonesian custom and their Indonesian students were, in an important respect, simply aligning themselves on one side of a conflict that was both deeper and more enduring than the narrow legal question of whether Islamic or customary rules would govern inheritance questions. ${ }^{17}$ Conceived most broadly, adat and Islam represent more than simply alternative sets of legal rules: they represent competing bases of social authority. From this broader and symbolically weightier perspective, the loss of jurisdiction over inheritance, which is everywhere regarded as a core religious concern for Muslims, represented a victory for anti-Islamic forces and a serious setback in the historic advance of Islam in the archipelago. ${ }^{18}$

${ }^{11}$ Lev, Islamic Courts, pp. 18-19.

12 Lev, Islamic Courts, p. 21. The Mahkamah Islam Tinggi was originally located in Batavia, but was moved to Surakarta during the war where it remained.

13 Staatsblad No. 116 (1937) discussed in Benda, The Crescent and the Rising Sun, p. 88 and Lev, Islamic Courts, p. 21.

14 For a discussion of the views of the adat law scholars as they relate to the Islamic courts, see Benda, The Crescent and the Rising Sun, pp. 65-68; and Lev, Islamic Courts, pp. 19-29. The ostensible reasons for Dutch support for custom over Islam were philosophical and scientific. Influenced by continental legal science, which viewed law as the organic outgrowth of a society's history and culture, the adat scholars promoted indigenous customary law as the only authentic expression of the ethos of Indonesian society. They supported their claims about the secondary place of Islam in the archipelago's legal culture by painstakingly cataloguing local customary practices which, they contended, demonstrated the limited extent to which Islamic rules were observed in fact. Of course, the promotion of local and particularistic customary law over universalistic Islam also served conservative Dutch political interests. Benda, The Crescent and the Rising Sun, p. 68.

15 Lev, Islamic Courts, pp. 196-197.

${ }^{16}$ See e.g. Hazairin, Hukum Kekeluargaan Nasional (Jakarta: Tintamas, 1962), pp. 4-5 condemning the reception theory as "a theory of the devil, that defies the faith of Muslims, defies God, defies the Koran, and defies the Traditions of the Prophet."

17 Lev, Islamic Courts, pp. 24-29.

18 Ibid. 
An effort was also launched in 1937 to reform the substantive law of marriage, although the initiative failed. ${ }^{19}$ For several decades, Indonesian women's groups had been agitating for legislation limiting or prohibiting polygamy and curbing the Muslim husband's power of unilateral repudiation. ${ }^{20}$ The colonial government's proposal would have established a registration procedure whereby a woman whose marriage had been registered gained legal protection against unilateral divorce and polygamy. The proposal was opposed both by Islamic groups, who saw it as an improper interference with the infallible and everlasting religious law, and by the major nationalist parties, who regarded it as an illegitimate intrusion by the Dutch into native affairs, and was withdrawn. ${ }^{21}$

With independence there occurred a number of changes of importance to Islamic courts, but the departure of the Dutch did not dramatically alter the terms of the debate over the courts or the balance of power between supporters and detractors. ${ }^{22}$ One development that proved critical was the creation of the Ministry (later Department) of Religion. ${ }^{23}$ The establishment of the Ministry, then unique in the Muslim world, made possible the consolidation of the entire Islamic administration under a single authority and ensured that Islamic institutions would be under the control of Islamic groups, rather than that of more secular minded nationalists who dominated the Ministry of Justice and the rest of the state bureaucracy. ${ }^{24}$ Also critical to the courts' survival was the emergence of Islamic political parties, which were able to check to some degree the secularizing and modernizing impulses of the executive bureaucracy. Although Islamic leaders often disagreed over issues relating to Islamic courts and many favored the eventual absorption of the Islamic courts into the civil judiciary, there was enough support for the continued existence of a separate Islamic court system to prevent the abolition of the courts or further encroachment on their powers. ${ }^{25}$ Thus, by the time the nation's first law on judicial organization and procedure was enacted following the transfer of sovereignty, ${ }^{26}$ Islamic interests could marshal enough clout to secure the recognition of the existence of Islamic courts, even though the drafters of the statute in the Justice Ministry clearly favored their abolition. ${ }^{27}$ The 1951 statute did not expressly authorize Islamic courts, but stated that provision for the administration of Islamic justice would be made through a separate

19 The proposed marriage ordinance is discussed in Benda, The Crescent and the Rising Sun, pp. 88-89; Jan Prins, "Adat law and Muslim Religious Law in Modern Indonesia," Welt des Islams I (1951): 283, 294-95; and Cora Vreede-de Stuers, The Indonesian Woman: Struggles and Achievements (The Hague: Mouton \& Co., 1960), pp. 108-110.

${ }^{20}$ On the early Indonesian women's movement see Vreede-de Stuers, The Indonesian Woman, pp. 89-99.

21 Benda, The Crescent and the Rising Sun, pp. 88-89; Prins, "Adatlaw and Muslim Religious Law," pp. 29495; and Vreede-de Stuers, The Indonesian Woman, pp. 108-110.

22 See generally, Lev, Islamic Courts, ch. 2, 3.

23 Lev, Islamic Courts, pp. 43-45.

24 Ibid.

25 See generally Lev, Islamic Courts, pp. 63-75.

26 Law No. 1 (1951) discussed in Lev, Islamic Courts, p. 65.

27 The drafters of the measure suggested that the legislature be consulted about transferring the functions of the Islamic courts to the civil courts. Lev, Islamic Courts, p. 65 . A 1948 law, never implemented because of events during the revolution, would have effected the immediate integration of the Islamic courts into the civil courts. Lev, Islamic Courts, pp. 64-65; Noeh and Adnan, Sejarah Singkat, pp. 53-54. 
148 Mark Cammack

government regulation ${ }^{28}$-language that provided the foundation for the eventual establishment of a nation-wide system of Islamic courts.

Following the passage of the 1951 law, the Ministry of Religion, which had taken over administration of the Islamic courts on Java and Madura in 1946, set about to unify, centralize, and, to the extent possible, expand the Islamic court system into those parts of the country where courts were not then formally established. ${ }^{29}$ Over the next several years the Ministry worked with local leaders to acquire control over existing Islamic tribunals and established a limited number of new courts by means of ministerial regulations. The Ministry was also able to use local religious affairs offices, which existed throughout the country, to assert some control over the administration of marriage and inheritance in areas without Islamic courts. Finally, in 1957 the cabinet approved a regulation authorizing the formation of Islamic courts everywhere in the outer islands where they did not already exist. ${ }^{30}$ Patterned after the Royal Decree of 1882, the 1957 regulation authorized the establishment of Islamic courts, labeled Pengadilan Agama/Mahkamah Syariah, wherever there were civil courts exercising a territorial jurisdiction co-extensive with the civil court. ${ }^{31}$ The new Islamic tribunals were to have the same collegial organization as the courts set up under the Dutch era regulations. ${ }^{32}$ Unlike the existing courts, however, the substantive competence of the new courts would include inheritance as well as marriage and divorce cases, 33 producing a disparity between the courts in Java, Madura, and South Kalimantan compared with the rest of the country.

The promulgation of the 1957 regulation, as a result of which there existed a legal basis for Islamic courts throughout the country, represented a significant victory for advocates of Islamic law. The issuance of the regulation was more a result of the persistent lobbying of the Ministry of Religion and a confluence of political developments that made the granting of concessions to Islam and the outer islands momentarily expedient than of any change in policy toward Islamic law. ${ }^{34}$ Shortage of funds prolonged the implementation of the regulation. By the early 1970s, however, first instance Islamic courts existed in most districts throughout the country, and additional appeals courts-four in Sumatra and one in Sulawesi-were added to existing appellate tribunals in Java and Kalimantan. ${ }^{35}$

Thus, the Islamic court system was able to survive and even expand in independent Indonesia despite opposition to the courts from some segments of the bureaucracy, especially the Ministry of Justice, whose lawyers-trained in the civil law tradition-considered the existence of sectarian tribunals to be incompatible with a

\footnotetext{
28 Lev, Islamic Courts, p. 65.

${ }^{29}$ On the expansion of the court system see Lev, Islamic Courts, pp. 75-92.

${ }^{30}$ Gov. Reg. No. 45 (1957) discussed in Lev, Islamic Courts, p. 89 and Noeh and Adnan, Sejarah Singkat, pp.

59-60. A government regulation requires approval by the full cabinet but not the legislature.

31 Gov. Reg. No. 45 Art. 1 (1957).

32 Ibid., Arts. 2, 6.

33 Ibid., Art. 4(1).

${ }^{34}$ Lev, Islamic Courts, p. 89.

${ }^{35}$ Noeh and Adnan, Sejarah Singkat, pp. 69-70.
} 
modern national state. ${ }^{36}$ But while defenders of Islamic courts had enough leverage to protect them against threats of abolition or absorption into the civil judiciary, the Islamic courts suffered from inadequate budgets and a general neglect that left them ill-housed and with staffs that were both too small and inadequately trained. ${ }^{37}$ Many courts, especially in the outer islands, did not have their own physical facilities; court sessions were held in the back rooms of other government offices or the residence of the court chairman. ${ }^{38}$ All Islamic courts suffered from insufficient support staff. Some courts did not have a full-time court chairman, but relied exclusively on part-time member judges. ${ }^{39}$ By comparison to civil court judges, Islamic court judges were badly paid and poorly educated. 40

The post-independence era also witnessed a number of efforts to enact legislative reforms of Islamic marriage law, none of which, however, resulted in changes to the substance of Islamic rules. A statute passed in 1946 required that all marriages, repudiations, and reconciliations be registered in the local religious affairs office. ${ }^{41}$ Failure to register could subject the party to a small fine, but did not affect the validity of the action. More ambitious proposals that would have affected substantive rights were considered by the legislature in both the late 1950s and again in the late 1960s, but none of the proposals was enacted. ${ }^{42}$

Although there were no similar legislative initiatives concerning Islamic inheritance law, the matter of inheritance provoked a scholarly debate in the 1950s and 60 s that laid the groundwork for developments in the late 1980s. The figure at the center of the debate, Professor Hazairin of the University of Indonesia, was Indonesia's most prominent and daring exponent of Islamic modernism, the jurisprudential theory that the original sources of Islamic law should be reinterpreted in light of contemporary social realities. ${ }^{43}$ Hazairin argued that the classical Islamic legal

\footnotetext{
36 The attitude of rivalry and mutual suspicion that has long characterized relations between the Ministries of Justice and Religion resurfaced recently in the controversy over the so-called Juvenile Courts Bill. In November of 1995 the Justice Department introduced a proposal for a new law regulating various legal issues relating to children, including adoption and guardianship. The proposal vested jurisdiction over these matters in the civil courts. See "Rancangan Undang-Undang tentang Peradilan Anak," in Mimbar Hukum 25 (1996): 131-155. The Department of Religion and Islamic organizations opposed the proposal on the ground that it derogated from the powers of the Islamic courts. After a long and acrimonious debate, the offending provisions were removed and the bill was finally passed in December of 1996. "Aturan Anak Nakal itu Lahir," Gatra (January 4, 1997).

${ }^{37}$ Information on the condition of the courts can be found in $\mathrm{H}$. Ichtijanto, "Pengadilan Agama Sebagai Wadah Perjuangan Mengisi Kemerdekaan Bangsa," Kenang kenangan Seabad Peradilan Agama di Indonesia Jakarta: Dep. of Religion, 1985), pp. 258-280; Lev, Islamic Courts, ch. 4; H. Mastur Jahri, "Memperingati Seabad Peradilan Agama yang Jatuh Pada Tahun 1982 ini," Kenang kenangan Seabad Peradilan Agama di Indonesia (Jakarta: Dep. of Religion, 1985), pp. 349-361.

${ }^{38}$ H. Ichtijanto, "Pengadilan Agama Sebagai Wadah Perjuangan," pp. 265-266; Lev, Islamic Courts, p. 112; H. Mastur Jahri, "Memperingati Seabad Peradilan Agama," p. 359.

${ }^{39} \mathrm{H}$. Ichtijanto, "Pengadilan Agama Sebagai Wadah Perjuangan," pp. 265-266.

40 Lev, Islamic Courts, pp. 104-112.

41 Law No. 22 (1946) discussed in Lev, Islamic Courts, pp. 53-58.

42 Lev, Islamic Courts, p. 139; Vreede-de Stuers, The Indonesian Woman, pp. 124-140.

${ }^{43}$ For brief discussions of Hazairin's views see B.J. Boland, The Struggle of Islam in Modern Indonesia (The Hague: Martinus Nijhoff, 1982), pp. 168-170 and Lev, Islamic Courts, p. 219. Hazairin's most important
} 
150 Mark Cammack

doctrines that developed in the Arabian Peninsula were incompatible with Indonesian circumstances, and advocated the development of a distinctively Indonesian school of Islamic law or "mazhab" alongside the four existing schools. He paid particular attention to inheritance law, arguing that the patrilineal bias of classical inheritance doctrine was incompatible with both Indonesian social realities and the spirit of the Koran. ${ }^{44}$

Hazairin's views won some adherents in academic circles, but had little influence on judges or policy makers. During this period, both the Islamic bureaucracy and the religious courts were dominated by "traditionalists" committed to following the legal doctrines (figh) of the early jurists as contained in the classical legal texts. ${ }^{45} \mathrm{~A}$ quarter century later, however, the principle of an Indonesian mazhab would provide part of the justification for state intervention in the development of Islamic legal doctrine.

The change in administration following the events of 1965 raised expectations among many Muslims that organized Islam would play a larger role in the country's public life in the new regime than it had under Sukarno. It soon became apparent, however, that Muslim support for Suharto in his bid for power-support that was probably critical to his success-would not translate into Muslim participation in the exercise of power once Suharto's authority was established. ${ }^{46}$ Upon assuming control, the new regime systematically set about to consolidate the primacy of the executive bureaucracy and to emasculate political parties and other non-state sources of political power. ${ }^{47}$ Although all groups challenging the dominance of the bureaucracy came under suspicion, during its first two decades, the Suharto government was especially repressive of Islamic groups, which were regarded as the chief threat to stability following the elimination of the communist party. ${ }^{48}$ Nor did strongly identified Muslims acquire influence within the bureaucracy, the upper echelons of which were dominated by military officers not oriented toward Islam. Indeed, beginning in 1971 organized Islam lost control of the Ministry of Religion, its traditional stronghold within the government, when Professor Mukti Ali, a Western trained educator with strong ties to neither of the major Islamic groups, was appointed Minister of Religion. ${ }^{49}$ An even more significant appointment was made seven years later when the Religion

works include Hazairin, Hukum Kewarisan menurut Qur'an dan Hadith (Jakarta: Tintamas, 1958) and Hazairin, Hukum Kekeluargaan Nasional (Jakarta: Tintamas, 1962).

44 Boland, The Struggle of Islam, pp. 169-70.

45 See generally Lev, Islamic Courts, ch. 7.

46 See generally Ruth McVey, "Faith as an Outsider: Islam in Indonesian Politics," Islam in the Political Process, ed. James P. Piscatori (Cambridge: Cambridge University Press, 1983), pp. 199-225.

47 See Benedict Anderson, “Old State and New Society: Indonesia's New Order in Comparative Perspective," Joumal of Asian Studies 42 (May 1983): 477-96, characterizing the change from the Sukarno to Suharto regimes as entailing a shift in emphasis from "national" to "state" interests.

48 See David Jenkins, Suharto and His Generals: Indonesian Military Politics 1975-1983 (Ithaca: Cornell Modern Indonesia Project, 1984), pp. 29-32, discussing the "Islam-phobia" of Suharto's inner circle of advisors.

${ }^{49}$ McVey, "Faith as an Outsider," p. 208. 
portfolio was given to General Alamsjah Ratu Perwiranegara, a military man and member of Suharto's inner circle of advisors. ${ }^{50}$

Muslim expectations that the New Order would be friendlier toward Islamic law than the Old also proved mistaken. ${ }^{51}$ By 1973, two years after the government scored a decisive victory over Muslim parties at the polls, Islamic courts were fighting for their survival. In July of that year the administration put forward a marriage law proposal which, on its face, would have thoroughly secularized Indonesian marriage law and effectively abolished much of the country's Islamic court system. 52 Both the Department of Religion and organized Islam were largely excluded from the preparation of the draft. ${ }^{53}$ Although this was ostensibly a Department of Justice initiative, the impetus for the proposal apparently came from the influential clique of informal Presidential advisors lead by Ali Murtopo and the group's Catholic dominated research arm, the Center for Strategic and International Studies. ${ }^{54}$ This group was not especially concerned about Islamic courts per se, but found the marriage law issue provided them with an opportunity to strike a blow at political Islam. 55

The proposal provided for a single set of marriage and divorce rules applicable to all Indonesians regardless of religion. It required civil registration for marriage and court approval for divorce and polygamy. ${ }^{56}$ Both divorce and plural marriage, moreover, would become subject to tight restrictions. ${ }^{57}$ Enforcement of the law was to be entrusted to the civil courts, ${ }^{58}$ which would have reduced the jurisdiction of the outer island courts to matters of inheritance only and left the Islamic courts in Java, Madura, and South Kalimantan with literally nothing to do.

\footnotetext{
50 Jenkins, Suharto and His Generals, p. 79. Because positions in the Department of Religion are not attractive to most university graduates, these changes in the leadership of the Department did not necessarily permeate the rank and file.

51 For instance, shortly after Suharto took over, Muslim groups mounted an effort to revive the so called Jakarta Charter, a constitutional provision imposing an obligation to carry out Islamic law, that had been considered and rejected in 1945. The Suharto government, however, was unreceptive. Allan A. Samson, "Islam in Indonesian Politics," Asian Survey 8 (1968): 1001, 1012-1013.

52 For a discussion of the terms of the proposal see Mark Cammack, "Islamic Law in Indonesia's New Order," The International and Comparative Law Quarterly 38 (1989): 53, 57-65; Muhammad Kamal Hassan, Muslim Intellectual Responses to "New Order" Modernization in Indonesia (Kuala Lumpur: Dewan Pustaka dan Bahasa, 1980), pp. 148-56; June Katz and Ronald Katz, "The New Indonesian Marriage Law: A Mirror of Indonesia's Political, Cultural, and Legal Systems," American Journal of Comparative Law 23 (1975): 65381.

53 "RUU Perkawinan, Aksi dan Reaksi," Tempo, September 8, 1973, pp. 6-8. See also Leo Suryadinata, Military Ascendancy and Political Culture: A Study of Indonesia's Golkar (Athens: Ohio University Center for International Studies, 1989), pp. 76-77.

54 Harold Crouch, The Army and Politics in Indonesia (Ithaca: Cornell University Press, 1978), p. 313. This "invisible cabinet" originated with the appointment of a small Presidential "private staff" in 1966. Although the private staff was officially disbanded in 1968 in response to student protests, a changing group of informal Presidential advisors continued to exercise great influence thereafter. Ibid., pp. 243, 307309; Jenkins, Suharto and His Generals, pp. 23-24.

55 Crouch, The Army and Politics in Indonesia, p. 313.

56 Katz and Katz, "The New Indonesian Marriage Law," p. 661.

57 Ibid.
} 
152 Mark Cammack

The proposal met with angry and determined Muslim opposition both inside and outside the legislature. ${ }^{59}$ At one point several hundred Muslim youth occupied the floor of the legislature, and the army had to be called in to restore order ${ }^{60} \mathrm{~A}$ solution to the conflict was reached only after high-ranking military officers initiated discussions with Muslim leaders outside the formal legislative process. ${ }^{61}$ The parties to this negotiation agreed to a framework for revising the bill, in which Muslim interests acceded to demands for legal restrictions on arbitrary divorce and polygamy in exchange for promises that the substantive law of marriage would not be altered and the role of the Islamic courts not diminished. ${ }^{62}$ A statute implementing this agreement was approved by the legislature in late 1973 and signed into law by the President as the 1974 Marriage Act. ${ }^{63}$

The effect of the 1974 Marriage Act on Indonesian Islamic law is a matter of dispute. Many Muslims have hailed Article 2(1) of the law, which states that a marriage is valid when it is performed according to the religious law of the parties, as marking the first formal recognition of Islamic rules as Indonesian law and the end of the hated reception theory. A more extreme version of this view interprets that provision as importing the entire corpus of Islamic marriage doctrine into state law. The Supreme Court and the Department of Religion, on the other hand, have been promoting a dramatically different interpretation of the Marriage Act, which attaches more importance to the positive content of the statute than to Islamic doctrine. ${ }^{64}$ According to this interpretation, the Act effects significant changes in the marriage law of Indonesian Muslims, including registration as a requirement for marriage and court approval for divorce and polygamy. It is my contention that the 1989 Religious Judicature Act is, at least in part, an effort to influence the outcome of the debate over the meaning of the Marriage Act.

\section{The 1989 Religious Judicature Act}

The Minister of Religion presented the government's proposal for a new law governing Islamic courts to the Indonesian legislature in December of 1988. Consideration of the bill continued throughout the following year, during which time it was widely debated in the public press. The public discussion focused primarily on the broad question whether a separate system of sectarian courts was appropriate for

\footnotetext{
58 Cammack, "Islamic Law in Indonesia's New Order," pp. 57-58.

59 For an account of the controversy provoked by the proposal, see Donald K. Emmerson, Indonesia's Elite: Political Culture and Cultural Politics (Ithaca: Cornell University Press, 1976), pp. 229-235.

60 "Ada 'Allahu Akbar' dari Luar," Tempo, 6 October 1973, pp. 6-7.

61 "Dan Lahirlah UU Itu-Dengan Afdruk Kilat," Tempo, 29 December 1973, pp. 5-8. See also Crouch, The Army and Politics in Indonesia, pp. 313-314. The meeting was apparently an attempt by General Sumitro, then head of the internal security apparatus, to exploit the marriage law controversy in his simmering rivalry with Ali Murtopo. Suryadinata, Indonesia's Golkar, pp. 77-78.

62 Katz and Katz, "The New Indonesian Marriage Law," p. 663.

63 Law No. 1 (1974). An English translation of the statute is contained in B. B. Hering, "A Translation of the Indonesian Marriage Law," ed. B. B. Hering, Indonesian Women: Some Past and Current Perspectives (Brussels: Centre D'Etude du Sud-Est Asiatique et de L'Extreme Orient, 1976), pp. 91-114. For a good summary of the law see Nani Soewondo, "The Indonesian Marriage Law and its Implementing Regulations," Archipel 13 (1977): 283-294.

64 See Cammack, "Islamic Law in Indonesia's New Order," pp. 63-65.
} 
an officially pluralist nation. ${ }^{65}$ That issue, however, was not really open to debate in 1989. By the time the Bill was introduced the survival of the Islamic courts was virtually assured as a result of changes made following the implementation of the 1974 Marriage Act. In December of 1989 the legislature approved the Bill with only minor changes from the original draft, and it was signed into law by the President shortly thereafter.

The Act is contained in 108 sections divided into seven chapters. As with all legislative enactments in Indonesia, it is accompanied by an official elucidation that provides a section by section commentary on the text.

Chapter I is labeled "General Provisions" and contains sections on the definitions, status, location, and organization of the Islamic courts. It defines the "Religious Judiciary" (Peradilan Agama) 66 as the "judiciary for adherents of Islam."67 This judiciary consists of "Religious Courts" (Pengadilan Agama), identified in the following chapter68 as courts of first instance, and "Religious High Courts" (Pengadilan Tinggi Agama), which exercise appellate jurisdiction. ${ }^{69}$ Together they "exercise judicial power" for Muslim litigants limited to civil matters specified in the Act. ${ }^{70}$ The first instance courts are to be located in municipalities (Kotamadya) or district (Kabupaten) capitals with territorial jurisdiction throughout the municipality or district. Appeals courts are to be located in the provincial capitals with province-wide jurisdiction. ${ }^{71}$

The specification of a uniform designation for Islamic courts throughout the country replaces the three different labels under which the courts had operated in the past. Like so much else in the Act, this change had already been effected by means of a Ministerial Decision several years earlier. ${ }^{72}$ In 1989, there were more than threehundred first instance Islamic courts operating in most districts and municipalities throughout the country, and appeals tribunals had been established in eighteen of the country's twenty-seven provinces. ${ }^{73}$

\footnotetext{
65 See Peradilan Agama dalam Wadah Negara Pancasila: Dialog tentang RUUPA, ed. H. Zuffran Sabrie (Jakarta: Pustaka Antara, 1990) which contains a collection of several dozen press reports focusing on this issue. The proposal encountered comparatively little serious opposition in the legislature. Initially, Golkar was divided over the Bill. Those opposed to the measure objected that it perpetuated legal dualism in violation of Pancasila. "Sebuah RUU dengan Lapang Dada," Tempo, 24 June 1989, p. 26. However, when the Golkar faction formally stated its position on the Bill, it came out in favor. The Democratic Party supported the Bill with reservations. Both the Unity Development Party and the Military faction strongly supported it. "Peradilan Agama: Kebutuhan atau Kecemasan," Tempo, 24 June 1989, p. 22.

66 The Democratic Party voiced strong public objection to the title of the Act on the ground that it establishes not "Religious" courts but Islamic courts. See e.g. "Pembahasan Judul RUUPA Berjalan Alot," Jawa Pos, 26 September 1989. It is fair to assume that the objection was not only to the accuracy of the label but also to the existence of a separate set of sectarian courts.

67 Chap. I, Art. 1(1). Unless otherwise indicated, citations to statutory authorities refer to the 1989 Act.

68 Chap. II, Art. 6.

69 Chap. I, Art. 1(2).

70 Chap. I, Art. 2.

71 Chap. I, Art. 4.

72 Decision of the Minister of Religion No. 6, January 28, 1980.

73 "Peradilan Agama: Kebutuhan atau Kecemasan," Tempo, 24 June 1989, p. 24. By 1996 the only provinces without Islamic High Courts were Bali and East Timor. Based on Department of Religion Statistics.
} 
154 Mark Cammack

The Act assigns responsibility for what is labeled "technical juridical" matters to the Supreme Court while the organization, administration, and finances of the courts are under the auspices of the Minister of Religion. ${ }^{74}$ This division of responsibility for Islamic courts between the Supreme Court and the Department of Religion represents a change from the practice that had prevailed until the late $1970 \mathrm{~s}$. As noted, the Ministry of Religion had assumed administrative control of the Islamic courts in 1946. As an adjunct to that administrative function, the Directorate of Religious Justice, the division of the Ministry responsible for the courts, had also exercised some control over the law the courts applied, and eventually acquired powers of appellate review in $1964 .{ }^{75}$ Around this same time Justice Ministry officials were urging the creation of an Islamic chamber in the Supreme Court to serve as a court of cassation for the Islamic system. ${ }^{76}$ For a time the Directorate of Religious Justice lent guarded support to this limited integration of the Islamic courts into the civil system as a means of improving the profile of the courts without entirely losing their identity. ${ }^{77}$ Other segments of the Islamic community-Islamic political leaders and probably most Islamic judgesopposed the idea on the ground that the courts should remain tied to the Islamic community rather than attaching themselves more firmly to a non-Islamic state. When a new Basic Law on Judicial Authority was passed in 1970, supporters of the idea of an Islamic chamber had enough influence to gain inclusion of a provision granting the Supreme Court review powers over all Indonesian courts, including the Islamic court system. ${ }^{78}$

Nothing was done to enforce the Supreme Court's powers with respect to Islamic courts until after the implementation of the Marriage Act. Then in 1977 the Supreme Court issued a regulation establishing procedures for Supreme Court review of Islamic court decisions. ${ }^{79}$ The Directorate of Religious Justice initially resisted the move, instructing Islamic courts not to cooperate with litigants seeking cassation in the Supreme Court. The conflict was finally resolved following a meeting between the Minister of Religion and the chairman of the Supreme Court that resulted in the appointment of six Supreme Court justices to an Islamic panel. ${ }^{80}$ This ushered in a new era in relations between the Department of Religion and the Supreme Court. By the time the Religious Judicature Bill was proposed, the Supreme Court had assumed a major role in the administration of the Islamic courts in addition to the exercise of its review powers over those courts.

\footnotetext{
74 Chap. I, Art. 5.

75 Lev, Islamic Courts, pp. 95-96.

76 Lev, Islamic Courts, pp. 70-75. The Department of Justice supported Religion's effort to retain administrative control over the Islamic courts in order to protect its own prerogative as the administrative head of the civil court system. The Indonesian bar had long advocated placing the civil courts under the auspices of the Supreme Court as a means of promoting their independence, and continues to do so. Lev, Islamic Courts, p. 74, n.15.

77 Lev, Islamic Courts, pp. 71-75.

78 Law No. 14, Ch. II, Art. 10(3) (1970).

79 See Cammack, "Islamic Law in Indonesia's New Order," pp. 66-67 and sources cited therein.

80 "Perkembangan Hukum Islam dan Peradilan Agama di Indonesia," in Kenang Kenangan Seabad Peradilan Agama di Indonesia (Jakarta: Department Of Religion, 1985), pp. 47-48.
} 
Chapter II of the Act governs the structure and composition of the courts. ${ }^{81}$ Among its more significant provisions are the rules treating the appointment and qualification of judges. The power to appoint and terminate judges is vested in the President as Head of State upon the recommendation of the Minister of Religion and the agreement of the Supreme Court. ${ }^{82}$ The provision granting the Supreme Court a voice in the selection of judges, which had been the practice for several years before the Act was proposed, formalized Supreme Court involvement in the management of the Islamic judiciary contrary to the earlier tradition of exclusive Religion Department control.

Articles 14 and 15 of Chapter II specify the qualifications for judges. Appointment as an Islamic judge requires, among other things, that the candidate be a civil servant, hold a law degree or a shariah degree, and be a Muslim. ${ }^{83}$ The requirements that all Islamic judges have academic credentials and civil service status represent a change from prior law. As noted, under the 1882 statute only the court chairman was a civil servant, and prior law did not specify any educational qualifications for judges, the vast majority of whom did not have university degrees. ${ }^{84}$ Both the educational qualification and civil service status for judges had been enforced as a matter of executive policy for several years before the statute was proposed, ${ }^{85}$ and by the time the Act was passed significant progress had already been made toward their full implementation. ${ }^{86}$ With the passage of the Act, all judges not meeting its requirements were retired. Since most of those who served as Islamic judges before the mid-1970s did not meet the qualifications required under the Act, the effect of the imposition of the new qualifications was dramatically to transform the Islamic judiciary over the space of less than two decades.

Chapter III specifies the powers of the Islamic courts. Article 49 states that "Religious Courts have the responsibility and authority to examine, decide, and resolve cases at the first instance between Muslims in the areas of: a) marriage; b) inheritance, testaments, and gifts, that are performed according to Islamic law; c)

\footnotetext{
81 Articles 7 and 8 provide that first instance courts are created by Presidential decree and high courts by statute. The first instance courts are to consist of the court "administration" (pimpinan) made up of the chair and deputy chair, member judges, clerks, secretarial staff, and the new position of bailiff/huissier (juru sita) necessitated by the courts' new enforcement powers. Chap. II, Arts. 9(1), 10(1). The high courts are made up of the administration, including a chair and deputy, high court judges as members, clerks and secretaries. Chap. II, Arts. 9(2), 10(2),(3).

82 Chap. II, Art. 15(1).

83 Chap. II, Art. 13. Appointment as a high court judge includes the same requirements as well as a minimum age and a requirement of at least fifteen years service as a first instance judge. Chap. II, Art. 14 . The other statutory employees are all appointed by the Minister of Religion. Chap. II, Arts. 36, 40, 47. None need be civil servants; all are required to be Muslims. Chap. II, Arts. 27-34, 39, 45. With the exception of the bailiff, all statutory employees are required to have some post-secondary education. Chap. II, Arts. 27-34, 39.

84 Lev, Islamic Courts, p. 111.

85 See Standarisasi Pengadilan Agama dan Pengadilan Tinggi Agama (Jakarta: Department of Religion, 1983), pp. 94-95. See also Cammack, “Islamic Law in Indonesia's New Order," pp. 68-70.

86 Between 1977 and 1985 the number of full time civil servant Islamic judges tripled, rising from 225 to 765. Cammack, "Islamic Law in Indonesia's New Order," p. 69. By 1989 the number of Islamic court judges had risen to over 1200. "Pengadilan Serambi Milik Kita Bersama," Tempo, 4 February 1989, p. 76. In 1983,401 of the total 680 full-time judges were college graduates compared to only 12 college degree holders among all chief judges a decade earlier. Cammack, "Islamic Law in Indonesia's New Order," p. 70.
} 
charitable foundations." 87 The high courts are granted appellate jurisdiction coextensive with the competence of the lower courts. ${ }^{88}$

The courts' jurisdiction over marriage is further specified as relating to "matters regulated in or based on applicable marriage legislation." 89 This vague reference is clarified in the elucidation as referring to the 1974 National Marriage Act. ${ }^{90}$ The elucidation then lists twenty-two specific subject areas relating to marriage that are treated in the National Marriage Act. The effect of granting the Religious Courts plenary authority to apply the Marriage Act for Muslims is significantly to expand the courts' powers. Prior to the passage of the Religious Judicature Bill, the competence of the Islamic courts extended only to those matters that had been treated in executive implementing regulations issued in $1975 .{ }^{11}$ All other matters had to be referred to the civil courts. The regulations that had been issued under the 1974 Marriage Act covered matters relating to the validity of marriage, including the granting of permission to enter a polygamous marriage or dispensation from statutory age requirements, and the procedures for dissolving marriages. They did not address child custody following divorce or any matters relating to financial obligations or property rights after termination of the marriage. The Supreme Court had held that in the absence of government regulations implementing the Act's provisions on these matters, they were to remain under the jurisdiction of the civil courts. The enumeration of powers in the elucidation to the Religious Judicature Act makes it clear that these matters are now within the authority of the Islamic courts.

The provision granting all Islamic courts power to decide issues of property distribution following death is likewise a change from prior law, since the Islamic courts for Java, Madura, and South Kalimantan had lost their inheritance jurisdiction in the 1930s. The Act clarifies the courts' inheritance powers as including "designation of heirs, designation of the estate, designation of individual shares, and distribution of the estate." 92 Resolution of disputes regarding ownership of property remains under the jurisdiction of the civil courts. ${ }^{93}$

As a practical matter the restoration of the courts' inheritance jurisdiction may not be as significant as it appears. First, although the courts for Java, Madura, and South Kalimantan lacked formal jurisdiction over inheritance matters prior to the passage of the Act, many people had been taking non-contentious inheritance questions to Islamic courts for "advisory opinions" (fatwa).94 These opinions were made enforceable by means of a private agreement to abide by the court's decision that was negotiated by

87 Chap. III, Art. 49.

88 Chap. III, Art. 51.

${ }^{89}$ Chap. III, Art. 49(2).

${ }^{90}$ Religious Courts Act, Law No. 7, Elucidation to Art. 49(2) (1989).

91 Supreme Court Directive of August 20, 1975. See also Cammack, "Islamic Law in Indonesia's New Order," pp. 65-66 and cases cited therein.

92 Chap. III, Art. 49(3).

${ }^{93}$ Chap. III, Art. 50.

${ }^{94}$ Lev, Islamic Courts, pp. 199-205. See also Mura Hutagalung, "Faktor-Faktor yang Menpengaruhi Mengapa Banyak Orang Menyelesaikan Masalah Kewarisan Melalui Pengadilan Agama," Hukum dan Pembangunan 13, no. 5 (September 1983): 409-416. 
the parties under the supervision of the court. Moreover, the Act includes an important limitation on the courts' inheritance jurisdiction buried in the introduction to the elucidation. It is there provided that before the initiation of proceedings the parties can decide to select the law that will be used in the division of the estate. This "choice of law" provision was hotly debated during the consideration of the Bill. ${ }^{95}$ The principle that the claimants to an estate be allowed to choose the legal regime governing distribution of property has its source in the historic debate over the extent to which Islamic rules had supplanted adat in matters of inheritance. The argument advanced by opponents of state enforcement of Islamic rules-that the state should not be a party to the Islamization of the country-prevailed, resulting in the provision for an election determining whether Islam or adat should govern distribution of property on death.

Chapter IV treats procedure in Islamic courts. The first part of the Chapter contains general provisions, beginning with the general rule that the procedural law to be followed in Islamic courts is that contained in the Code of Civil Procedure and applicable in the civil courts, except as specifically provided in the Act. ${ }^{96}$ This first part also contains provisions relating to the means of exercise of judicial power generally as well as provisions unique to Islamic courts. For instance, one section requires that justice be carried out "with simplicity, expedition, and minimal expense," and also provides that decisions and decrees be opened with the recital of the Bismillah, ${ }^{97}$ the ritual invocation of God's name that occurs at the beginning of each surah of the Koran. Other provisions require that in order to be valid, decisions and decrees must be announced in open court, 98 and that decisions and decrees must recite the reasons and basis for the result, including specific statutory provisions or unwritten law. ${ }^{99}$

Part two of the Chapter lays out special procedural rules for divorce actions. It begins, however, with the general injunction that "Divorce can only be carried out (dilakukan) in open court after the court has attempted unsuccessfully to reconcile the parties." 100 This provision is potentially very significant if construed as denying the validity of a Muslim husband's unilateral repudiation of his wife or talak. However, the language of the provision, which is identical to that contained in a provision of the National Marriage Act, ${ }^{101}$ is ambiguous. As will be discussed below, the comparable provision in the Marriage Act was widely interpreted as rendering judicial divorce mandatory, giving rise to penalties for those who do not comply, but not affecting the legal validity of a non-conforming talak. As will become clear, moreover, the whole question of the legal effect of extra-judicial talak was a principal theme of the debate during the legislative consideration of the bill.

\footnotetext{
95 See e.g. "Dua Pasal RUUPA Harus Dihapus," Serambi Indonesia, August 5, 1989; "Disepakati Pilihan Hukum," Suara Karya, October 5, 1989; "Akhirnya Lancar, Pembahasan Selesai Lebih Cepat Satu Hari," Kompas, October 5, 1989; "RUUPA: Bisakah Mandiri?" Kiblat, October 23-November 5, 1989. 
158 Mark Cammack

The Act next specifies three different procedural schemes for three different types of divorce: talak divorces; "complaint" (gugat) divorces; and divorces on grounds of adultery. The procedures for talak divorces, which generally track corresponding portions of the executive regulations issued in 1975 to implement the Marriage Act, ${ }^{102}$ provide for a husband to recite the repudiation formula or talak-"I divorce you"-in court under judicial supervision. According to classical Islamic doctrine, a husband has an absolute power to repudiate his wife at any time for any reason. Under the Act, following the 1975 regulation, a husband wishing to repudiate his wife must file a petition requesting the court "to convene to witness his pronouncement of the talak." 103 In a modest change designed to provide greater protection to wives, the husband must file his petition with the court in the district where his wife resides, rather than in his own district, as permitted by the 1975 regulation. ${ }^{104}$

The husband's petition must recite the name, age, and residence of both parties, as well as "the reasons that form the basis for the talak divorce." 105 The Act does not specify what reasons qualify as sufficient reasons. ${ }^{106}$ The court must examine the petition in closed session within thirty days after the file is enrolled by the clerk. ${ }^{107}$ In keeping with the policy of attempting to reduce the frequency of divorce, the court is charged with attempting to reconcile the couple at the first hearing 108 and then throughout the pendency of the case. ${ }^{109}$ If the couple cannot be reconciled and if there are "sufficient reasons for divorce the court decrees that the petition is granted." 110

The Act provides that the wife may appeal the court's decree declaring that there exist grounds for a talak.111 Only after the decree has become final through the exhaustion of all appeals or the expiry of the period for filing an appeal does the court schedule a hearing for the purpose of witnessing the husband's talak. ${ }^{112}$ This procedure was established by means of a Supreme Court Circular issued in 1985.113 Before the issuance of the circular, the wife could appeal the sufficiency of the husband's reasons for divorcing her only after the divorce became effective through the husband's pronouncing the talak. This procedure was unacceptable from the Muslim perspective because the talak was an accomplished fact that could in nowise be invalidated through

\footnotetext{
102 Gov. Reg. No. 9, Arts. 14-18 (1975).

103 Chap. IV, Art. 66(1).

${ }^{104}$ Chap. IV, Art. 66(2). There is an exception to this rule when the wife "intentionally leaves their common home without the petitioner's permission." Ibid.

105 Chap. IV, Art. 67.

106 A list of grounds for divorce is contained in the official elucidation of the 1974 National Marriage Act, Art. 39(2), and also in the government's implementing regulation for the 1974 Act. Gov. Reg. No. 9, Art. 19 (1975).

107 Chap. IV, Art. 68.

108 In order to facilitate the reconciliation function the parties are required to appear personally at this first session unless one of the parties lives out of the country. Chap. IV, Art. 82(2).

109 Chap. IV, Arts. 69, 82(1), (4).

110 Chap. IV, Art. 70(1).

111 Chap. IV, Art. 70(2).

112 Chap. IV, Arts. 70(3), (4). The wife must be notified of the hearing, but the husband or his delegated representative can recite the talak in her absence. Chap. IV, Art. 70(4), (5).

113 Supreme Court Circular No. 13, August 19, 1985.
} 
a judicial decision on appeal. Reformers, on the other hand, were anxious that there be some means for an appeal of the first instance court finding of sufficient grounds in order to preserve the contentious nature of the action and impose meaningful limits on the husband's power to divorce his wife. The device used by the statute of simply deferring the pronouncement of the talak until any appeals have been completed provides an adequate solution for the narrow problem it addresses. However, the problem of appealing a talak exemplifies a broader difference in interests and outlooks that the Act must negotiate. Stated most broadly, the difference is between a view which sees law as emanating from the law-making organs of the state and a view which sees the source of law in the revealed word of God.

A woman wishing to be divorced from her husband proceeds under the "complaint" procedure outlined in the following part. ${ }^{114}$ Like the rule setting forth the talak procedure, the complaint procedure largely follows the pattern set out in the implementing regulations to the 1974 Marriage Act. ${ }^{115}$ Furthermore, though not explicitly stated in the text, the drafters undoubtedly contemplated the continuation of the courts' practice under the 1975 regulations. The Islamic courts had interpreted the complaint procedure in the regulations as simply vindicating the courts' powers to grant divorces initiated by women in accordance with Indonesian Islamic doctrine. The Shafi'i school of Islamic law as applied in Indonesia recognized a number of means by which a dissatisfied wife could terminate her marriage. 116 Unlike her husband, all the divorce options for wives required cooperation of the court. In applying the Marriage Act and its implementing regulation, the courts had essentially assimilated traditional Islamic doctrine to the list of grounds for divorce stated in the positive law. ${ }^{117}$ That is, the specific grounds stated in the statute were identified with one of the avenues for divorce recognized in Islamic law. For instance, the statutory grounds of irreconcilable differences was interpreted as a codification of the Islamic syiqaq procedure. Syiqaq is ostensibly a mechanism for resolving differences between spouses through appointment of arbiters for each. However, it had evolved into a divorce procedure once it became recognized that the husband's arbiter, typically one of the judges, had the power to terminate the marriage if reconciliation efforts failed. Following the effective date of the Marriage Act and its implementing regulations, the Islamic courts "applied" the rule regarding divorce based on irreconcilable differences by appointing arbiters as required by the syiqaq procedure. The Act contains no list of grounds for complaint divorces. It was clearly anticipated that the courts would continue to apply the substantive law in effect before the Religious Judicature Act was passed, which was understood to be essentially Islamic doctrine. Indeed, the Act expressly provides for the appointment of arbiters when the complaint is "based on the grounds of syiqaq."118

114 Chap. IV, Arts. 73-86

115 Gov. Reg. No. 9, Arts. 20-36 (1975). In the Regulation the complaint procedure is theoretically available to either husband or wife. The Act makes it clear that it is for the only party to the marriage who would have occasion to use it, that is, the wife. Chap. IV, Art. 73.

116 The substantive law of divorce applied by Indonesian Islamic courts prior to the passage of the Marriage Act is summarized in Lev, Islamic Courts, pp. 153-178.

117 See Cammack, “Islamic Law in Indonesia's New Order," pp. 63-65.

118 Chap. IV, Art. 76. 
160 Mark Cammack

The complaint initiating the proceeding is to be filed in the court in the district where the complainant resides unless the wife has left the marital residence without permission, ${ }^{119}$ a change designed to redress the unequal legal standing of women. The complaint procedure contains the same charge to the judge to try to reconcile the couple ${ }^{120}$ and the same rules and timetable for examining the complaint as are contained in the talak procedure. 121

On the issue of proof, the Act states that a copy of a judgment of conviction is sufficient proof when the asserted ground for the complaint is that the husband has been convicted of a crime and sentenced to prison, 122 and that the court can order the husband to submit to a physical examination when the basis of the complaint is that he suffers from a handicap or illness which prevents him from performing his conjugal obligations. ${ }^{123}$ As observed, the statute also sets out the syiqaq procedure. Apart from these references, however, there is no specification of the kinds or quantities of evidence required to prove either a talak or a complaint claim. The Act states that the court's "decision" on the complaint is to be announced in open court and that the divorce and its consequences are deemed to have occurred from the time the court's decision acquires the force of law. ${ }^{124}$

The third type of divorce action regulated by yet another set of procedural rules is divorce based on adultery. The explanation for the separate treatment of adultery cases lies, once again, in Islamic doctrine, specifically the procedure known as lian. The lian divorce procedure derives from the criminal law. ${ }^{125} \mathrm{~A}$ Muslim husband who suspects his wife of adultery takes four solemn oaths that his wife has committed unchastity or that the child born to her is not his. The wife is then offered the chance to deny the accusation with four oaths of her own. The requirement that the parties swear four times to the same thing has its source in the requirement of testimony from four witnesses to prove the crime of adultery, and if the wife refuses to make her denial she stands convicted of that crime. If she does deny, then the only effect of the procedure is permanently to dissolve the marriage.

The proposal codified the traditional lian procedure, but broke from tradition by making it available to either spouse. Not surprisingly, the inclusion of the lian rule was controversial. ${ }^{126}$ Publicly expressed opposition to the provision insisted that the rule had no place in an essentially procedural statute because of its substantive character, and that the extension of the lian option to wives was inconsistent with Islamic doctrine. ${ }^{127}$ It seems likely that a more important but unstated basis for opposing the

\footnotetext{
119 Chap. IV, Art. 73(1).

120 Chap. IV, Arts. 82(1), (4).

121 Chap. IV, Art. 80.

122 Chap. IV, Art. 75.

123 Chap. IV, Art. 75.

124 Chap. IV, Art. 81.

${ }^{125}$ See Joseph Schacht, An Introduction to Islamic Law (Oxford: Oxford University Press, 1964), p. 165.

126 See e.g., "PDI Minta RUUPA Diluruskan," Media Indonesia, September 26, 1989; “Tidak Ada Maksud untuk Mengubah Hukum Islam," Pelita, October 3, 1989.

127 See H. Achmad Roestandi and Muchjidin Effendie, Komentar atas Undang-Undang No. 7 Tahun 1989 tentang Peradilan Agama (Bandung: Nusantara Press, 1991), p. 18 stating that two (unidentified) legislative
} 
proposal is the highly irrational character of the rule. In the enacted version the rubric for the procedure is changed from "lian" to "divorce on account of adultery." Another amendment provides for a different procedure depending on whether the charge is brought by husband or wife. If the husband makes the oath of accusation the case proceeds and is resolved according to the lian procedure. When a wife accuses her husband then the case is resolved under the "applicable rules of procedure."128

The inclusion of the lian procedure reflects the basically modernist jurisprudential outlook of the Act. ${ }^{129}$ Although, as discussed above, Islamic modernism authorizes the reinterpretation of the original sources to meet changing needs, the limits of legal change are highly restrictive. The standard modernist position authorizes a reinterpretation of rules based on authorities deemed uncertain, but insists on strict adherence to those legal doctrines that are based on divine texts that are certain. ${ }^{130}$ Because the lian procedure is regulated in some detail in the Koran, ${ }^{131}$ the premises of modernist jurisprudence require its recognition.

The influence of Islamic modernism in the preparation of the Act is indicative of a more general shift in the position of modernist Islam vis-à-vis the Indonesian state. In contrast to the situation before 1970s, the upper echelons of the Department of Religion are now dominated by modernists, the most notable example being $\mathrm{H}$. Munawir Sjadzali, the two-term Religion Minister who shepherded the Act through the legislature and whose legal reform proposals in the 1980s sparked a firestorm of controversy. ${ }^{132}$ The overhaul of the Islamic judiciary that resulted from the imposition of new educational qualifications in the early 1980 s has also changed the profile of the

factions had objected to the lian proposal on the grounds that it was substantive rather than procedural and violated Islamic doctrine. See also H. Munawir Sjadzali, "Landasan Pemikiran Politik Hukum Islam dalam Rangka Menentukan Peradilan Agama di Indonesia," Hukum Islam di Indonesia: Pemikiran dan Praktek, ed. Eddi Rudiana Arief (Bandung: PT Remaja Rosdakarya, 1991), pp. 41-67 containing the government's response to objections to the draft in which the Minister of Religion rejects the GOLKAR faction's argument that the matter of divorce on grounds of adultery is fully addressed in the Marriage Act.

128 Chap. IV, Arts. 87, 88.

129 The simple "modernist v. traditionalist" distinction obscures a great deal of diversity of viewpoint within those broad approaches. It is also true that there are other interpretive traditions that cannot fairly be labeled either modernist or traditionalist. Nonetheless, the basic distinction between those who advocate adherence to the interpretations of the classical era jurists (traditionalists) and those who advocate a return to the original sources (modernists) remains a useful one.

130 See Al Yasa Abu Bakar, “Beberapa Teori Penalaran Fiqih dan Penerapannya," Hukum Islam di Indonesia: Pemikiran dan Praktek, ed. Eddi Rudiana Arief (Bandung: PT Remaja Rosdakarya, 1991), pp. 173208 for a succinct statement of this view by an Indonesian Islamic scholar.

131 Koran xxiv, pp. 6-9. See also Asaf A. A. Fyzee, Outlines of Muhammadan Law, 4th ed. (Delhi: Oxford University Press, 1974), p. 166. Modernist influence is more apparent in the recently implemented Compilation of Islamic Law, which is discussed above. The most obvious example of refusal to move beyond the terms of scripture is in the provisions on inheritance. For instance, the chapter that defines intestate shares includes the provision that female children receive one-half the share of male children. Apart from being inconsistent with modern notions of equality, this rule was never widely practiced in Indonesia. Its inclusion in the Compilation is explainable only on the modernist principle that there can be no derogation from those legal rules that are clearly stated in the Koran.

132 See e.g. Polemik Reaktualisasi Ajaran Islam (Pustaka Panjimas: Jakarta, 1988) containing a collection of responses to the Minister's proposals for inheritance law reform. 
Islamic bench. Once the preserve of traditionalist judges trained exclusively in pesantren, the courts are now overwhelmingly staffed by graduates of the State Islamic Institutes, which are decidedly reformist in orientation. ${ }^{133}$

The remainder of Chapter IV and the last three chapters of the Act address a variety of technical matters including costs, ${ }^{134}$ the responsibilities of court personnel, ${ }^{135}$ and a set of concluding provisions repealing conflicting statutes and providing that the Act shall take effect on the date that it is enacted. ${ }^{136}$

\section{An Indonesian Mazhab: The Case of Talak Divorces}

Like many legislative enactments, the 1989 Religious Judicature Act is not an expression of any one purpose or coherent ideology or set of policies. It reflects, rather the outcome of a negotiation in which no single interest or outlook was able completely to have its way.

To illustrate the various conflicting tendencies embodied in the Act, I propose to take a closer look at one narrow aspect of the statute-its treatment of divorces initiated by men. The provision governing talak divorces was one of the more contentious features of the proposal. The reason the talak provision engendered controversy is that the question of the husband's power unilaterally to repudiate his wife focuses the disagreement between two conflicting points of view. It engages both the jurisprudential conservatism of the advocates of state enforcement of Islamic law and the statist orientation of the New Order's leaders. An examination of the Act's treatment of the issue in the context of the broader history of New Order policy toward Islamic law shows that the Act failed to resolve the tension between the two tendencies. Instead it effects an unsteady compromise, the precise terms of which are the subject of continuing negotiation.

In order to appreciate the tensions that lie behind the divorce provisions of the Religious Judicature Act, it is useful to recount the course of divorce reform legislation beginning in the early 1970s. The government's 1973 draft national marriage law would have abolished the talak by converting divorce into a contentious judicial

133 See Cammack, "Islamic Law in Indonesia's New Order," p. 70. Nur Ahmad Fadhil Lubis has confirmed the basically modernist outlook of the current Islamic judiciary. In a survey of approximately one hundred Islamic court judges conducted in the late 1980s, a large majority agreed that the figh texts are not always compatible with Indonesian circumstances and agreed on the need for reformation of Islamic institutions to meet changing needs. Nur Ahmad Fadhil Lubis, Islamic Justice in Transition: A Socio-Legal Study of the Agama Court Judges in Indonesia (PhD dissertation, UCLA, 1994), pp. 322-23.

134 The Act states the general rule that "Litigation costs for marriage actions are charged to the petitioner or the complainant." Chap. IV, Art. 89(1). Included in the statutory costs are fees for clerks, witnesses, experts, translators, evidentiary reconstructions, and costs of summonses and other official announcements. Chap. IV, Art. 90(1).

135 The chapter is clearly not a comprehensive treatment of the subject. For instance, nothing in this chapter or any other treats the voting rules for the court or even the number of judges required for a court quorum. It was assumed, presumably, that matters not addressed in the statute will be regulated according to prior practice. That which is included in the chapter is not particularly noteworthy. Most often mentioned is the specification of responsibilities of the bailiff/huissier in enforcing court orders. This is significant because prior to the passage of the Act, enforcement of Islamic court orders had to be obtained through the civil courts.

136 Chap VII, Art. 107, 108. 
proceeding. The draft stated that anyone wishing to divorce must prove statutory grounds in court, included an exhaustive list of legal grounds, and required that the court's "decision" terminating the marriage had to be announced in open court. ${ }^{137}$

The divorce provisions in the enacted version differed in important respects from the initial draft. The treatment of divorce in the statute itself is very brief, by its own terms incomplete, and on its face extremely obscure. The statute states only that marriage can be terminated by death, divorce, or court decision; that divorce must be "performed" in court; that before a divorce can be carried out there must be sufficient reasons; and that procedures for divorce would be set forth in separate implementing regulations. ${ }^{138}$ The statute itself does not specify what reasons qualify as "sufficient reasons" for divorce, but a list of grounds for divorce is contained in the official elucidation accompanying the Act. ${ }^{139}$

The intent of these obscure provisions became clear only in the government's implementing regulations ${ }^{140}$ and the practice of the courts. Under the regulations as interpreted by the courts, a Muslim man wishing to divorce his wife must file a petition with the Islamic court for permission to repudiate his wife. The regulation directs the courts to examine the petition to determine if it is based on statutory grounds, and to convene for the purpose of witnessing the husband's repudiation only if the court finds the couple can no longer live together in harmony. After witnessing the husband's talak, the court verifies the divorce by issuing a "Certificate Respecting the Occurrence of a Talak."141

The appeal of this scheme from the Islamic perspective is its recognition of the talak as the mechanism for dissolving the marriage. In the Muslim understanding the statute does not alter the substance of the divine law but simply institutes procedures for its enforcement. Instead of prescribing legal grounds or conditions for divorce, the statute seeks to control the incidence of divorce by imposing legal requirements for the use of the husband's talak. From the Muslim perspective at least, the law regulates the occurrence of legally significant events, rather than declaring new legal meanings. And since the law addresses itself exclusively to when a man may repudiate his wife and not to the issue of when the repudiation is effective, a talak pronounced in violation of the Act may be illegal but is nonetheless efficacious. ${ }^{142}$

137 Draft Marriage Law, Arts. 40, 41, 42(e) (1973).

138 National Marriage Act, Law No. 1, Arts. 38-40 (1974).

139 National Marriage Act, Law No. 1, Elucidation to Art. 39(2) (1974).

140 In fact the regulations are far from clear. Indeed, there seems to have been a deliberate effort by the drafters to avoid explicitly describing the divorce procedure as a court sanctioned talak. The word talak occurs only once, a single reference buried in the elucidation to the regulation. Even that reference seems unnecessarily obscure. It states simply that the procedure laid out in the regulation governs talak divorces. 141 Gov. Reg. No. 9, Arts. 14-17 (1975).

142 The popular interpretation of the Marriage Act as essentially a dead letter was advertised around the country in 1985 when Oma Irama, a popular film and music personality, married a second wife without obtaining judicial approval and then divorced his first wife through an extra-judicial talak, neither of which is permitted under the Marriage Act. At the time, Oma Irama was easily Indonesia's most popular entertainer and enjoyed wide name recognition throughout the country. His actions and example carried special significance because of his strong identification with Islam. Both his music and films are filled with explicit religious themes. 
164 Mark Cammack

The Religious Judicature Act abjures the coy approach of the Marriage Act and explicitly provides that the procedure for divorces initiated by men involves a courtsanctioned talak. Like the Marriage Act, however, the language of the Bill equivocates on the question whether compliance with its procedures, though unquestionably obligatory, is necessary for the divorce to be valid.

The debate over the proposal clearly indicated the existence of conflicting views on that question. At one point during the consideration of the Bill, the Unity Development Party-the government contrived coalition that functions as the only authorized voice for Muslim interests in the legislature-proposed an amendment to Article 66 that would have recognized the validity of extra-judicial talak. ${ }^{143}$ Under the proposed amendment, which went nowhere, a husband who either wished to or "had already repudiated his wife" could petition the court to certify his action. ${ }^{144}$ Despite the failure of the amendment, the Unity Development faction maintained in its comment on the final draft of the Bill that the language of the statute did not preclude a finding that extra-judicial talak are valid. Citing the Basic Law on Judicial Authority for the proposition that judges may take account of "the legal values that exist in society," the comment argued that, "in calculating the wife's waiting period [following an extrajudicial talak], due consideration must be given to religious precepts." 145 What this means, expressed ever so indirectly, is that judges can find that extra-judicial talak are legally effective. The Armed Forces faction countered with its own interpretation of the relevant provisions in its final written comments to the Bill. Its comment states flatly that the statutory language means that "as a matter of law talak divorces are valid only if performed in court." 146

There was no attempt to resolve this difference before passage of the law. An unequivocal declaration that extra-judicial talak either do or do not have the force of law would undoubtedly have created a serious obstacle to the Bill's approval. This absence of clarity on such an important point was not viewed as problematic. Like many legislative enactments, this statute was not regarded as providing a definitive resolution of what the law is, but as providing a basis for a continuing negotiation over what the law should be. Moreover, the ambiguous and inconclusive character of the

News of Oma Irama's having taken a second wife and then divorcing his first made headlines in Jakarta's sensationalist "red press" for months. It was a deep embarrassment to government efforts to assert authority over Moslem marriage practices. Popular opinion of Oma Irama's actions varied. He was criticized for his insensitivity toward his first wife, who was unaware of the polygamous marriage. He was also faulted for not respecting Indonesian law. But there was seemingly universal recognition of the explanation for his actions as an acknowledgement of the ultimate authority of the religious law of marriage and divorce.

143 See Roestandi and Effendie, Komentar, 18; "Tidak Ada Maksud untuk Mengubah Hukum Islam," Pelita, October 3, 1989; “Masalah Cerai-talak Alot," Suara Karya, October 3, 1989.

144 “Tidak Ada Maksud untuk Mengubah Hukum Islam,” Pelita, October 3, 1989.

145 "Pendapat Akhir Fraksi Persatuan Pembangunan DPR-RI terhadap Rancangan Undang-Undang tentang Peradilan Agama," in H. Achmad Roestandi and Muchjidin Effendie, Komentar atas UndangUndang No. 7 Tahun 1989 tentang Peradilan Agama (Bandung: Nusantara Press, 1991), pp. 213-223.

146 "Pendapat Akhir Fraksi ABRI atas Rancangan Undang-Undang tentang Peradilan Agama," in H. Achmad Roestandi and Muchjidin Effendie, Komentar atas Undang-Undang No. 7 Tahun 1989 tentang Peradilan Agama (Bandung: Nusantara Press, 1991), pp. 199-212. 
provision provided the opening for the Supreme Court and the Department of Religion gradually and quietly to promote their interpretation of what the law means.

A 1990 circular containing instructions for the implementation of the Act indicates the direction the Supreme Court wishes to take the law and the means by which this is being accomplished. It states that "A talak divorce is in principle a contentious marriage action between the two parties to the case, and as a consequence the judicial product from the judges must have the form and title of decision with an order in the form of decree."147 The import of labeling the judges' output as a "decision" is to give or attempt to give the proceeding a judicial cast. This is in line with the general purpose of the directive which is to discourage the treatment of talak proceedings as simply ministerial ceremonies that result in an official recognition of the occurrence of a talak. By characterizing the proceeding as a contentious action, the circular emphasizes the judges' role as adjudicators having the power to grant or withhold approval of the divorce subject to the husband's proving legislatively prescribed grounds. The change represents at best a partial step toward the eventual aim of acquiring state control over Islamic divorces. But it is precisely by means of such obscure and incremental actions that the government is attempting to move its agenda forward.

Another much more significant vehicle by which the Supreme Court and Department of Religion are pressing an alternative interpretation of Islamic divorce rules is the Compilation of Islamic Laws. The Compilation is an Indonesian language manual of rules covering marriage, divorce, inheritance, and charitable foundations. It was drafted under the direction of the Department of Religion and the Supreme Court over a period of several years, 148 and given the force of law in 1991 through a presidential decree. ${ }^{149}$ In addition to the classical texts of Islamic legal doctrine, other sources that were surveyed in the preparation of the Compilation included works on Islamic law by Indonesian scholars, the rulings of Indonesian Islamic organizations, the decisions of Indonesian Islamic courts, and legislation from other countries. The ostensible purpose of the project was to provide certainty and uniformity in the application of Islamic law. It has also been the means by which the government has attempted to promote an understanding of Islamic law consistent with its aims.

The Compilation provides a more comprehensive treatment of the law of divorce than the Religious Judicature Act, including some thirty-six articles on the subject. The general approach tracks the Marriage Act and the Religious Judicature Act in setting up two procedures, one available only to men, in which the husband repudiates his wife in court, and the other for women. Like the Religious Judicature Act, the Compilation does not explicitly declare extra-judicial talak invalid. But the suggestion in the Compilation that a talak without judicial approval does not have the force of law is stronger than in the Act. The Compilation, like the Act, states that a divorce can only be performed in court ${ }^{150}$ and that a husband who wishes to repudiate his wife must file

147 Supreme Court Circular No. 2 (April 3, 1990).

148 A description of the project by the Supreme Court Justice who chaired it can be found in Bustanul Arifin, "Kompilasi: Fiqh dalam Bahasa Undang-Undang," Pesantren 2, no. 2 (1985): 25-30.

149 Pres. Ins. No. 1 (June 10, 1991).

150 Compilation of Islamic Laws, Chap. XVI, Art. 115. 
166 Mark Cammack

a petition with the court to convene for that purpose. ${ }^{151}$ But the Compilation also says that "A talak is a declaration of the husband in the presence of the members of the court that constitutes one cause of the dissolution of marriage."152 Read literally, this language would seem to indicate that an extra-judicial repudiation is not a "talak" and therefore is of no effect. Another provision states that "Divorce takes effect from the moment it is expressed in the presence of the members of the court."153 This provision likewise suggests that a husband's attempt to repudiate his wife outside of statutory procedures is ineffective, though the use of the generic word for divorce rather than the word talak creates some ambiguity.

That which is obliquely intimated in the Compilation of Islamic Law is stated with unmistakable clarity in a comment on the text written by a Justice of the Supreme Court. ${ }^{154}$ The article, entitled "Codifying the Abstractions of Islamic Law," is contained in a periodical published by the Department of Religion and designated as required reading for all Islamic judges. Sounding a popular modernist refrain, the article begins by distinguishing figh-temporal rules-from shariah-the eternally correct path of life. ${ }^{155}$ The author goes on to explain that the figh that were derived by the medieval jurists and contained in the classical texts are not "Islamic law," since they represent only the opinions of their authors. Nor do the Koran and the Traditions comprise Islamic law since they hardly present a comprehensive treatment of legal problems. Thus, the author concludes, in the figh and the Koran Indonesian society has only "abstractions" of Islamic law. ${ }^{156}$ Hence the necessity for a codification of these abstractions in the Compilation of Islamic Laws.

The author then proceeds to elaborate his jurisprudential theory for the derivation of legal rules from the divine sources, and summarizes the aims and content of the Compilation. Among the avowed purposes of the Compilation is to "banish the understanding [of law] as a private affair." The traditional understanding of Islamic law, the author writes, has been that the principles of the law are regarded as a private matter between the individual and God. As a result, it is a matter in which the state may not interfere. But with the implementation of the Compilation, the application of the law is no longer left in the hands of individuals. "The emergence of the Compilation inaugurates a new era in Indonesian history, in which Islamic law has been elevated to the status of valid civil law that has a public character and can be enforced by the instrumentalities of the state."157

The author also offers an analysis of the substance of the Compilation, including the divorce provisions. As interpreted by the Supreme Court Justice, the talak procedure is "elevated to the status of a contentious proceeding," and he states

151 Compilation of Islamic Laws, Chap. XVI, Art. 129.

152 Compilation of Islamic Laws, Chap. XVI, Art. 117 (emphasis added).

153 Compilation of Islamic Laws, Chap. XVI, Art. 123.

154 M. Yahya Harahap, “Informasi Materi Kompilasi Hukum Islam: Mempositifkan Abstraksi Hukum Islam," Mimbar Hukum 3, no. 5 (1992): 21-63.

155 Ibid., p. 22.

156 Ibid.

${ }^{157}$ Ibid., pp. 29-30. 
unequivocally that extra-judicial talak "are not valid and not binding." 158 With this the government has successfully achieved the essence of what it failed to accomplish with its original secular marriage law proposal in 1973. The differences between the failed legislative proposal and the doctrine as it has been developed are in the mechanism by which the divorce is actually effected-by means of the husband's court-supervised talak-and the symbolic underpinning of the rules. Unlike the marriage law proposal, the asserted basis for the authority of the rules in the Compilation is as Islamic law. By means of the Compilation, the government seeks to transcend the conflict between state and religious lawmaking authority. Although the authority of the rules remains grounded in religion, the state now becomes the authoritative interpreter of the religious tradition. As a result, it is no longer Islamic law, but Indonesian Islamic law that regulates intimate social relations. ${ }^{159}$ Once a challenge to state lawmaking, Islam now becomes its vehicle.

\section{Conclusion}

The Religious Judicature Act effects an unstable accommodation between two opposing outlooks. On the one hand the Act shows the unmistakable influence of Islamic modernism. Modernist legal theory embraces the use of human reason to reinterpret the original sources of Islamic law in light of contemporary needs and circumstances, but only within defined limits. While modernism rejects the absolute authority of the figh as the temporal product of a different social and historical context, it insists on a strict, literal enforcement of those doctrines that have a clear textual basis in the primary sources-the Koran and the Hadith. ${ }^{160}$

The more interesting implication from the Act has to do with the Indonesian state. The recent evidence from Islamic law suggests that the adoption by the New Order of a more Islamic demeanor has not significantly tempered the regime's statist impulses. Behind the appearances there is a remarkable continuity in New Order policy toward Islamic law over the course of nearly twenty-five years. In the early 1970s powerful elements within the government perceived a political advantage in weakening or abolishing Islamic courts and marginalizing Islamic doctrine. By the late 1980s a changed political context had induced the regime to change its posture toward Islamic legal institutions. ${ }^{161}$ Instead of restricting the scope of Islamic law and curtailing the

158 Ibid., p. 52.

159 As Justice Harahap put it, "It is as if Indonesia has created its own doctrine (fiqih) and school (mazhab), distinct from the schools that have existed in the past." Ibid., p. 37.

160 Clifford Geertz summed up the failure of Islamic modernism or "scripturalism" to escape the constricting influence of textual literalism: "Stepping backward in order better to leap is an established principle in cultural change ... But in the Islamic case the stepping backward seems often to have been taken for the leap itself, and what began as a rediscovery of the scriptures ended as a kind of deification of them." Clifford Geertz, Islam Observed: Religious Development in Morocco and Indonesia (Chicago: University of Chicago Press, 1968), p. 69.

161 Cf. R. William Liddle, "The Islamic Tum in Indonesia: A Political Explanation," Journal of Asian Studies 55 (August 1996): 613-634 arguing that the Suharto government's support for the reformist oriented Association of Muslim Intellectuals or ICMI is designed to derive political advantage from the Islamization of Indonesian society. For a different view of the significance of ICMI see Robert W. Hefner, "Islam, State, and Civil Society: ICMI and the Struggle for the Indonesian Middle Class," Indonesia 56 (1993): 1-35. 
168 Mark Cammack

powers of Islamic courts, a different group of power brokers began enfranchising the religious courts and enforcing Islamic doctrine. Although the government's attitude toward official Islam had seemingly reversed itself, its more basic objective of acquiring control over Indonesian family law remained unchanged. Having settled on a policy of cultivating rather than confronting Islam, the government set about to assert greater influence over Islamic courts and to establish itself as the authoritative interpreter of a distinctively Indonesian Islamic legal tradition. Rather than competing with Islam for legislative authority, the government is seeking to appropriate the power to declare Islamic law. Instead of defeating Islam, the regime has decided to confiscate it.

How far the current accommodation between Islamic modernism and New Order statism can be maintained remains to be seen. There is an inherent tension between a view which believes in and feels entitled to state enforcement of a set of fixed religious doctrines, and the premises of state positivism, which locate an absolute and indivisible legal sovereignty in the lawmaking organs of the state. ${ }^{162}$ If my analysis is correct, moreover, the government is nourishing the present modus vivendi with Islamic modernism by encouraging, or at least tolerating, a level of misapprehension of its intentions. Insofar as the government has indicated a commitment to enforcing Islamic doctrine as interpreted by the Islamic community, those indications are misleading. ${ }^{163}$ Although the government's regulatory efforts are now articulated with a vocabulary supplied by Islam, the regime's basic objective of expropriating control over Indonesian family law remains unchanged.

162 See John Henry Merryman, The Civil Law Tradition: An Introduction to the Legal Systems of Western Europe and Latin America, 2d ed. (Stanford: Stanford University Press, 1985), pp. 19-22; Gianfranco Poggi, The Development of the Modern State: A Sociological Introduction (Stanford: Stanford University Press, 1978), pp. 87-92.

163 Cf. e.g. H. Muhammad Daud Ali, "Soal Anak Sudah Diatur Syariah," Mimbar Hukum 25 (1996): 33-38, in which a leading modernist scholar of Islamic law states, in opposing a proposal for a statute governing juvenile courts, that adoption and other matters relating to children are regulated in the original sources of Islamic law, and that state rules contrary to Islamic doctrine will not be obeyed. 